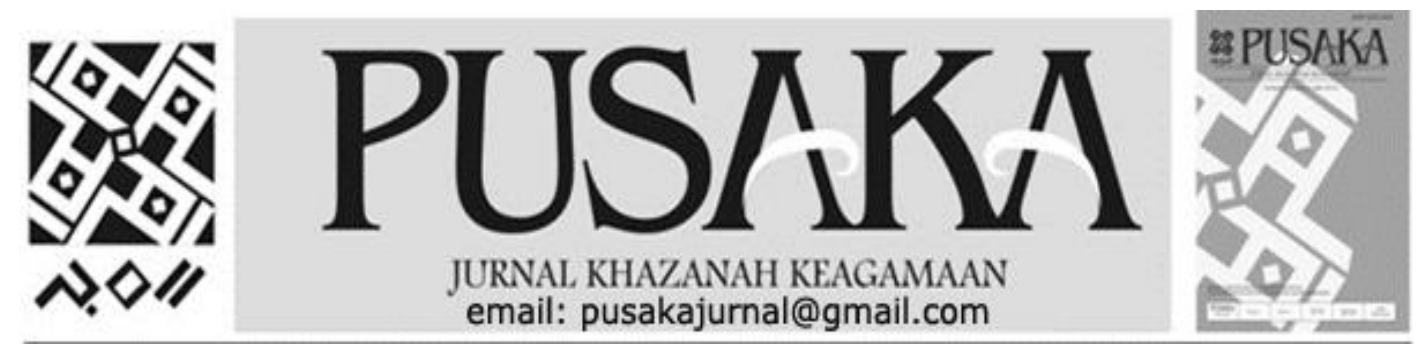

\title{
Problematika Pemanfaatan Buku Pendidikan Agama Islam dan Budi Pekerti di Sekolah Dasar Kota Kendari
}

\author{
The Problems of Utilization Books on Islamic Religion and Budi Pekerti at \\ Kendari City Elementary School
}

\section{Syarifuddin}

Balai Penelitian dan Pengembangan Agama Makassar

Jl.A.P.Pettarani No.72 Makassar. Telp:0411-452952

Email: syarifuddinamir84@yahoo.com

\begin{tabular}{|c|c|}
\hline Info Artikel & Abstract \\
\hline $\begin{array}{c}\text { Diterima } \\
2 \\
\text { Juli } \\
2018\end{array}$ & $\begin{array}{l}\text { Dalam pembelajaran Pendidikan Agama Islam dan Budi Pekerti, keberadaan buku } \\
\text { menjadi urgen oleh karena itu, penelitian ini mencoba memotret problematika } \\
\text { pemanfaaan PAI Sekolah Dasar di Kota Kendari. Sekolah Dasar yang menjadi } \\
\text { sasaran yaitu satu Sekolah Dasar unggulan diwakili oleh SDN } 12 \text { Baruga dan } \\
\text { Sekolah Dasar non unggulan yaitu SDN } 12 \text { Mandonga.Temuan penilitain ini yaitu; } \\
\text { Kurikulum yang digunakan di SDN } 12 \text { Baruga yaitu Kurikulum } 2013 \text { untuk Kelas } \\
1 \text {, Kelas } 2 \text {, Kelas } 4 \text { dan Kelas } 5 \text {, dipadukan dengan materi Kurikulum KTSP } 2006 \text {. } \\
\text { Sementara buku yang digunakan yaitu buku terbitan Kementerian Pendidikan dan } \\
\text { Kebudayaan untuk kelas } 1 \text { dan kelas } 4 \text { serta buku terbitan Tiga Serangkai untuk } \\
\text { yang lainnya. Sementara buku PAI yang digunakan di SDN 12 Mandonga yaitu } \\
\text { buku kurikulum KTSP } 2006 \text { dari penerbit Erlangga untuk Kelas } 1 \text {, Tiga Serangkai } \\
\text { untuk Kelas } 2 \text {. Kelas } 3 \text { dan Kelas } 5 \text {, sertaYudhistira untuk Kelas } 4 \text { dan Kelas } 6 \text {. } \\
\text { Problem pemanfaatan buku PAI di sekolah secara umum yaitu kurangnya peran } \\
\text { pengambil kebijakan dalam penyediaan buku sehingga belum mencapai rasio } 1: 1 .\end{array}$ \\
\hline $\begin{array}{l}\text { Revisi I } \\
\quad 2 \\
\text { Oktober } \\
2018\end{array}$ & $\begin{array}{l}\text { Disamping itu, kurangnya diklat, bimbingan teknis maupun sosialisasi yang dapat } \\
\text { mengkatkan kompetensi bagi guru PAI. Dari sisi konten buku problem yang } \\
\text { dikeluhkan yaitubahasa yang digunakan oleh Imasih kurang sederhana serta materi } \\
\text { masih dianggap kurang. } \\
\text { Kata Kunci: Buku PAI, Sekolah Dasar, Pembelajaran PAI. }\end{array}$ \\
\hline $\begin{array}{l}\text { Revisi II } \\
13 \\
\text { Oktober } \\
2018\end{array}$ & $\begin{array}{l}\text { In the study of Islamic Religion and Character Education, the existence of the book } \\
\text { becomes urgent, therefore, this study tries to portray the problem of using PAI } \\
\text { Primary Schools in Kendari City. Primary schools that are the target of one } \\
\text { excellent Primary School is represented by SDN } 12 \text { Baruga and Primary School } \\
\text { non-superior namely SDN } 12 \text { Mandonga. The findings of this research are; The } \\
\text { curriculum used in Baruga } 12 \text { Elementary School is the } 2013 \text { Curriculum for Class } \\
1 \text {, Class } 2 \text {, Class } 4 \text { and Class } 5 \text {, combined with the material of the } 2006 \text { KTSP } \\
\text { Curriculum. While the book used is the book published by the Ministry of } \\
\text { Education and Culture for grades } 1 \text { and grade } 4 \text { and published books Tiga } \\
\text { Serangkai for the others. While the PAI book used in SDN } 12 \text { Mandonga is the } \\
\text { KTSP } 2006 \text { curriculum book from Erlangga publishers for Class } 1 \text {, Tiga Serangkai } \\
\text { for Class } 2 \text {. Class } 3 \text { and Class } 5 \text {, and Yudhistira for Class } 4 \text { and Class } 6 \text {. Problems } \\
\text { in using PAI books in schools in general are lack of role of policy makers in the } \\
\text { supply of books so that they have not reached a } 1: 1 \text { ratio. In addition, there is a } \\
\text { lack of training, technical guidance and socialization that can improve competency } \\
\text { for PAI teachers. In terms of the problem book content that complained of, the } \\
\text { language used by it was still not simple and the material was still considered } \\
\text { lacking. } \\
\text { Keywords: PAI book, Elementary, Learning PAI. }\end{array}$ \\
\hline
\end{tabular}




\section{PENDAHULUAN}

Negara berdasarkan pada Ketuhanan Yang Maha Esa. Demikian bunyi pasal 1 ayat 29 Undang-undang Dasar 1945. Filosofi ini harus menjadi patron utama dalam membangun bangsa ini di berbagai bidang termasuk bidang pendidikan. Selanjutnya pada Pasal 31 ayat 3 Undang-undang Dasar 1945, disebutkan bahwa "Pemerintah mengusahakan dan menyelenggarakan satu sistem pendidikan nasional yang meningkat keimanan dan ketakwaan serta akhlak mulia dalam rangka mencerdaskan kehidupan bangsa yang diatur dengan undang-undang." Atas dasar itulah dirumuskan Visi dn Misi Pendidikan Nasional dengan visi makro yaitu terwujudnya masyarakat madani sebagai bangsa dan masyarakat Indonesia baru dengan tatanan kehidupan yang sesuai dengan amanat proklamasi Negara Kesatuan Republik Indonesia melalui proses pendidikan. Lebih lanjut Visi mikro pendidikan nasional adalah terwujudnya individu manusia baru yang memiliki sikap dan wawasan keimanan dan akhlak tinggi, kemerdekaan dan demokrasi, toleransi dan menjunjung hak asasi manusia saling pengertian dan berwawasan global.

Dalam upaya membangun moral bangsa berdasarkan UUD 1945, Visi dan Misi dan Pendidikan Nasional serta regulasi-regulasi turunannya, yang pada intinya berdasar pada Ketuhanan Yang Maha Esa dengan menciptakan manusia yang berakhlak mulia, maka pendidikan agama di sekolah seharusnya menjadi prioritas utama oleh pemerintah. Di samping itu beradsarkan Undang-undang Nomor 20 tahun 2003 Tentang Sistem pendidikan Nasional Pasal 12 ayat 1, "Adalah hak setiap peserta didik mendapatkan pendidikan agama sesuai dengan agama yang dianutnya dan diajarkan oleh pendidik yang seagama." Namun fakta dan realitas di lapangan, perhatian pemerintah akan keberadaan pendidikan agama khususnya di sekolah masih sangat minim. Salah satu contoh misalnya, mata pelajaran pendidikan agama tidak dijadikan sebagai standar kelulusan dalam ujian nasional. Sehingga pada akhirnya siswa di sekolah lebih mengutamakan mata pelajaran lain daripadamata pelajaran pendidikan agama.

Secara spesifik, kajian ini mencoba memaparkan salah satu proses implementasi Pendidikan Agama Islam di Sekolah Dasar. Agama Islam dipilih karena merupakan agama mayoritas. Sementara sasaran pada Sekolah Dasar dengan pertimbangan bahwa pendidikan agama Islam harus ditanamkan secara dini mulai dari tingkat pendidikan dasar. Pendidikan Agama Islam dan Budi Pekerti didefenisikan sebagai pendidikan yang memberikan pengetahuan dan keterampilan serta membentuk sikap, dan kepribadian peserta didik dalam mengamalkan ajaran agama Islam dan juga merupakan pendidikan yang berlandaskan pada akidah yang berisi tentang keesaan Allah swt sebagai sumber utama nilai-nilai kehidupan bagi manusia dan alam semesta. (Direktorat Pendidikan Agama Islam Direktorat Jenderal Pendidikan Islam Kementerian Agama RI., 2014: 2). Implementasi Pendidikan Agama Islam di sekolah dewasa ini 
ditengarai mengalami kegagalan seiring semakin rendahnya tingkat moralitas bangsa ini karena terjadinya tindakan amoral seperti korupsi, penyalahgunaan narkoba, pembegalan, pencurian, pemerkosaan dan lain sebagainya. Penelitian Badan Litbang dan Diklat Kementerian Agama yang disampaikan oleh Atho Muzhor di Tempo pada 2004 sebagaimana dikutip oleh Muhaimin, menyebutkan:

Salah satu kelemahan proses pelaksanaan pendidikan agama Islam di sekolah adalah keterbatasan sarana/prasarana, sehingga pengelolaan cenderung seadanya. Pendidikan agama yang diklaim sebagai aspek yang penting seringkali kurang diberi prioritas dalam urusan fasilitas. Selain itu, metodologi pendidikan agama kurang mendorong penjiwaaan terhadap nilai-nilai keagamaan. Buku paket pendidikan agama juga belum memadai untuk membangun kesadaran beragama, memberikan keterampilan fungsional keagamaan dan mendorong perilaku bermoral dan berakhlak mulia pada peserta didik (Muhaimin, 2009: 2526).

Penelitian yang lain juga dilakukan oleh Balai Litbang Agama Makassar yang diterbitkan dalam buku "Reformulasi Buku Paket di Madrasah" menyebutkan bahwa kurangnya buku penunjang pelajaran Pendidikan Agama di sekolahsekolah juga menjadi salah satu penyebab kurang maksimalnya sistem transfer pengetahuan dan desain yang ditetapkan oleh kurikulum tanpa inisiatif dan kreatifitas untuk mencari bahan bacaan lainnya, terlebih secara kuantitas, ketersediaan buku di perpustakaan sekolah juga sangat terbatas (As'ad, et.al., 2009). Implementasi Pendidikan Agama Islam yang menjadi pokok utama dalam kajian disana sini masih memiliki banyak problem. Fakta bahwa terdapat banyak masalah yang terjadi pada implementasi pendidikan agama di sekolah diantaranya yaitu berkenaan dengan keterbatasan standar sarana dan prasarana sekolah. Misalnya masih banyak sekolah yang mayoritas guru dan muridnya beragama islam tetapi tidak memiliki sarana ibadah seperti musholla.

Dalam tataran teknis di kelas terkait dengan implementasi pendidikan agama Islam dalam hal ini adalah sumber belajar atau buku pelajaran PAI menjadi salah satu sumber masalah. Buku sebagai media pembelajaran dalam arti terdiri dari perangkat lunak (software) dan perangkat keras (hardware). Perangkat lunak yang dimaksud yaitu isi atau pesan bahan ajar tersebut sedangkan perangkat keras yaitu peralatan bahan ajar itu sendiri yaitu buku (Susilana dan Riyana, 2009: 7). Kedua komponen ini harus ada dan sesuai dengan kemampuan dan kebutuhan siswa dalam pembelajaran PAI.

Kebutuhan atas keberadaan buku Pelajaran PAI di sekolah adalah sesuatu yang mutlak harus dipenuhi oleh sekolah, namun ada saja sekolah menganaktirikan buku PAI dibandingkan dengan buku mata pelajaran lainnya. Di samping itu juga, salah satu problem yang masih 
sangat terasa di banyak sekolah yaitu keberadaan buku paket pendidikan agama yang kuantitasnya masih di bawah standar. Dari aspek kuantitas, buku yang tersedia harus memenuhi rasio 1:1 atau satu buku teks pelajaran diperuntukkan bagi seorang siswa. Buku teks pelajaran yang digunakan di sekolah-sekolah harus memiliki kebenaran isi, penyajian yang sistematis, penggunaan bahasa dan keterbacaan yang baik, dan grafika yang fungsional, sebagaimana tercantum dalam Pasal 43 Peraturan Pemerintah Nomor 32 tahun 2013 tentang Perubahan Atas Peraturan Pemerintah Nomor 19 Tahun 2005 tentang Standar Nasional Pendidikan.

Terkait secara teknis Implementasi Pendidikan Agama (Islam pada kajian ini) di sekolah, penelitian ini menyorot pemanfaatan buku paket di Sekolah Dasar di Kota Kendari. Pemilihan Sekolah Dasar sebagai sasaran penelitian didasarkan pada asumsi bahwa penanaman nilai-nilai agama pada siswa harus dimulai sejak dini.

Berdasarkan latar belakang tersebut, maka yang menjadi permasalahan pokok dalam penelitian ini adalah bagaimana Problematika Pemanfaatan Buku Pendidikan Agama Islam di Sekolah Dasar di Kota Kendari? Pokok masalah tersebut kemudian diturunkan pada beberapa pertanyaan penelitian sebagai berikut:

1. Bagaimana Ketersediaan Buku Pendidikan Agama Islam di Sekolah Dasar di Kota Kendari?

2. Bagaimana mekanisme pemanfaatan buku-buku paket PAI di Sekolah Dasar di Kota Kendari?

3. Bagaimana problem yang dihadapi oleh pendidik dan peserta didik dalam memanfaatkan buku PAI di Sekolah Dasar di Kota Kendari?

Tujuan penelitian ini adalah untuk memperoleh jawaban yang akurat terhadap pertanyaanpertanyaan tersebut yang diangkat sebagai masalah penelitian, yaitu:

1. Memaparkan ketersediaan Buku Pendidikan Agama Islam di Sekolah Dasar di Kota Kendari;

2. Mendeskripsikan mekanisme pemanfaatan buku-buku paket PAI di Sekolah Dasar di Kota Kendari;

3. Mendeskripsikan problem yang dihadapi oleh pendidik dan peserta didik dalam memanfaatkan buku PAI di Sekolah Dasar di Kota Kendari.

Hasil Penelitian ini diharapkan menjadi acuan dan pertimbangan bagi Sekolah Dasar, Kementerian Agama dan Kementerian Pendidikan dan Kebudayaan beserta segenap jajarannya dalam mengatasi problem pemanfaatan buku PAI-BP di Sekolah Dasar, baik secara kualitatif maupun kuantitatif sehingga pembelajaran menjadi efektif.

Teori yang digunakan dalam kajian ini adalah teori pemanfaatan sumber belajar. Menurut Kamus Besar Bahasa Indonesia, pemanfaatan bermakna menjadikan ada manfaat dengan kata lain adalah proses, cara, perbuatan memanfaatkan (Pusat Bahasa Deparetemen Pendidikan Nasional, 
2009: 982). Sudjana dan Rivai sebagaimana dikutip oleh Abu Muslim, mengatakan bahwa "sumber belajar adalah suatu daya yang bisa dimanfaatkan guna kepentingan proses belajar mengajar baik secara langsung maupun tidak langsung, sebagian atau keseluruhan". Dari defenisi ini bisa dimaknai bahwa sumber belajar adalah segala sesuatu yang baik yang didesain menurut sifatnya dapat dimanfaatkan dalam kegiatan pembelajaran (Muslim, 2016: 264). Selanjutnya, pemanfaatan sumber belajar dalam proses pembelajaran sebagaimana dikutip dari Yunanto adalah aktivitas, cara dan proses dalam memanfaatkan sumber belajar untuk pencapaian tujuan pembelajaran yang ditetapkan untuk memperoleh hasil belajar yang maksimal (Muslim, 2016: 264).

Penelitian ini menggunakan metode kualitatif dengan memotret problematika pemanfaatn Buku PAIBP di Sekolah Dasar di Kota Kendari. Sekolah Dasar yang menjadi sasaran penelitian yaitu: SDN 12 Baruga sebagai sekolah dasar unggulan dan SDN 12 Mandonga sebagai sekolah dasar non unggulan. Data yang dibutuhkan penelitian ini bersumber dari: Kantor Kementerian Agama, Dinas Pendidikan dan Kebudayaan, Badan Pusat Statistik, Pengawas PAI-BP, Kepala Sekolah, Guru PAI-BP, dan tulisan-tulisan yang relevan. Analisis data dalam penelitian kualitatif dilakukan sejak sebelum memasuki lapangan, selama di lapangan, dan setelah selesai di lapangan. Meskipun demikian lebih difokuskan selama proses di lapangan bersamaan dengan pengumpulan data. Salah satu ciri penelitian kualitatif adalah peneliti merupakan instrumen utama dalam proses penelitian (Sugiyono, 2008: 59). Oleh karena itu, dalam penelitian ini analisis data telah dilakukan sejak studi pendahuluan, dilanjutkan saat penelitian ini berlangsung hingga berakhirnya proses pengumpulan data dan akhirnya dilanjutkan pada penyusunan laporan penelitian.

\section{PEMBAHASAN}

Potret UmumPembelajaran PAIBP di Sekolah Dasar di Kota Kendari

Berdasarkan data Kementerian Pendidikan dan Kebudayaan Kota Kendari tahun 2015, jumlah Sekolah Dasar di Kota Kendari sebanyak 129 SD dengan status negeri sebanyak 116 sekolah dengan status negeri dan 13 sekolah berstatus swasta.

Adapun Guru Pendidikan Agama Islam di Sekolah Dasar di Kota Kendari secara keseluruhan berjumlah 183 orang yang tersebar di seluruh Sekolah Dasar negeri maupun swasta. Dari jumlah keseluruhan tersebut, sebahagian besar berstatus PNS yaitu sebanyak 146 orang, sedangkan sisanya yaitu 37 orang berstatus Non PNS. Sementara data Guru PAI pada Sekolah Dasar yang sudah tersertifikasi yaitu sebanyak 126 orang dan yang belum tersertifikasi sebanyak 57 orang.

\section{Profil Sekolah Dasar Sasaran a. SDN 12 Baruga Kendari}

SDN 12 Baruga beralamat di Jalan Abu Nawas no 2 Kota Kendari Kelurahan Bende Kecamatan Kadia Kota Kendari. Letak sekolah ini cukup strategis di persimpangan jalan protokol berada di pusat 
jantung Kota Kendari dekat dengan Kantor Balai Kota Kendari dan alunalun kota serta pusat perkantoran sehingga akses ke sekolah sangat mudah baik menggunakan kendaraan pribadi maupun angkutan umum. Sekolah yang mulai beroperasi pada tahun 1984 merupakan sekolah unggulan di Kota Kendari dengan segudang prestasi dan menjadi sekolah pilot project penerapan kurikulum 2013 dengan status akreditasi A.

Pada tahun pelajaran 2014/2015, jumlah total siswa yaitu 1002 siswa yang tersebar pada 24 rombongan belajar dengan rincian; 932 orang beragama Islam, 56 orang beragama Protestan, dan 8 orang beragama Hindu. Data lengkap siswa SDN 12 Baruga dapat dilihat pada tabel berikut:

Tabel 1. Jumlah Siswa SDN 12 Baruga Tahun Pelajaran 2014/2015

\begin{tabular}{|l|l|c|c|c|c|}
\hline No & Kelas & Laki-laki & Perempuan & Jumlah & Jumlah Kls \\
\hline 1 & Kelas 1 & 76 & 93 & 169 & 5 \\
\hline 2 & Kelas 2 & 65 & 80 & 145 & 5 \\
\hline 3 & Kelas 3 & 83 & 103 & 186 & 4 \\
\hline 4 & Kelas 4 & 55 & 82 & 137 & 3 \\
\hline 5 & Kelas 4 Aksel & 13 & 16 & 29 & 1 \\
\hline 6 & Kelas 5 Aksel & 16 & 11 & 27 & 1 \\
\hline 7 & Kelas 5 & 70 & 78 & 157 & 3 \\
\hline 8 & Kelas 6 & 75 & 77 & 152 & 3 \\
\hline Jumlah & 453 & 549 & 1002 & 24 \\
\hline
\end{tabular}

Pembiayaan operasional sekolah berasal dana Bantuan Opersional Sekolah (BOS). Sebagai sekolah unggulan, prasarana ruang sekolah ini cukup lengkap hanya saja lokasi relatif cukup sempit dengan luas lahan $2.050 \mathrm{~m}^{2}$. Prasarana ruangan sekolah ini dapat dilihat pada tabel berikut ini:

Tabel 2. Prasarana Ruangan SDN 12 Baruga Tahun Pelajaran $2014 / 2015$

\begin{tabular}{|l|l|l|l|}
\hline No & Nama Ruangan & Jumlah & Tahun \\
\hline 1 & Ruang Kepala Sekolah & 1 & 1985 \\
\hline 2 & Ruang Adminsitrasi & 1 & 1985 \\
\hline 3 & Ruang Guru & 1 & 1985 \\
\hline 4 & Ruang Kelas & 15 & 2001 \\
\hline 5 & Ruang Perpustakaan & 1 & 2014 \\
\hline 6 & Ruang UKS & 1 & 2009 \\
\hline 7 & Ruang Musholla & 1 & 2000 \\
\hline 8 & Ruang Gudang & 1 & 2000 \\
\hline 9 & Ruang WC & 7 & 2008 \\
\hline 10 & Ruang Kantin & 1 & 2014 \\
\hline 11 & Ruang Tunggu|Orang Tua & 1 & - \\
\hline
\end{tabular}

Dari data tersebut di atas, sarana penunjang pembelajaran yang tersedia di sekolah yang secara khusus terkait dengan pelajaran PAI hanya musallah.

\section{Visi Sekolah}

Unggul dalam prestasi, berakhlak mulia, ber IPTEK dan berbudaya lingkungan

\section{Misi Sekolah}

a. Melaksanakan kedisiplinan warga sekolah (guru, karyawan dan siswa)

b. Melaksanakan proses pembelajaran aktif, inovatif, kreatif, efektif/efesien dan menyenangkan

c. Membentuk sumber daya manusia yang unggul di berbagai bidang

d. Melaksanakan kegiatan rohis, rokris, dan rohin pada setiap Jumat pagi

e. Menyediakan sarana dan prasarana yang diperlukan dalam kegiatan pembelajaran 
untuk mendukung pengembangan potensi peserta didik agar berkembang secara optimal

f. Membangun citra sekolah sebagai mitra terpercaya di masyarakat melalui komite sekolah.

g. Mengintergrasi nilai pendidikan karakter ke dalam semua mata pelajaran

h. Menerapkan manajemen partsispatif, transparan dan akuntabel

i. Menciptakan lingkuangan sekolah yang aman, rapi, bersih, dan nyaman sebagai sumber pembelajaran

j. Menanamkan kepedulian sosial, lingkungan cinta damai, cinta tanah air, semangat kebangsaan dan hidup demokratis

k. Melaksanakan program pencegahan, pengurangan, pemanfaatan sampah (mendaur ulang sampah)

1. Mewujudkan sekolah yang aman, sejuk, rindang, dan indah (asri) untuk mendukung terwujudnya Sekolah Adiwiyata.

Sebagai sekolah yang menjadi bagian dari Pilot Project penerapan Kurikulum 2013 (K13), maka sejak tahun pelajaran 2013/2014 untuk semua mata pelajaran diterapkan K13 masing-masing pada Kelas I dan Kelas IV. Pada tahun pelajaran 2014/2015, penerapan K13 dilanjutkan pada Kelas I, Kelas II, Kelas IV dan Kelas V. Sedangkan untuk kelas III dan kelas IV masih menggunakan KTSP.

\section{Personel Guru PAI-BP}

Guru PAI-BP di SDN 12 Baruga ada dua orang yaitu: $\mathrm{Hj}$.
Nurdiah, A.Md., S.Pd.I, lulusan Strata 1 pada Jurusan PAI. Ia diangkat sebagai PNS dalam jabatan Guru PAI sejak tahun 2004 dan sudah tersertifikasi. Sejak tahun 1986 menjadi guru honor di Pesantren Ummu Shabri pada mata pelajaran Biologi. Secara khusus sudah mengikuti Diklat Guru PAI 1 kali. Sudah mengikuti Pelatihan lebih dari 5 kali dan beberapa pelatihan baik skala nasional maupun lokal

Syamsuhak, A.MA., Diploma jurusan Guru Umum PNS dalam jabatan Guru PAI sejak tahun 1986 dan sudah tersertifikasi. sudah mengikuti Diklat Kurikulum 1 kali. Sudah mengikuti Pelatihan lebih dari 5 kali dan beberapa pelatihan baik skala nasional maupun lokal

\section{b. SDN 12 Mandonga Kendari}

SDN 12 Mandonga di Jl. Imam Bonjol No. 99 Kecamatan Mandonga Kota Kendari. Walaupun jarak sekolah ini sebenarnya tidak terlalu jauh dari pusat Kota Kendari, namun jalur utama ke sekolah ini cukup berliku dan berada di ketinggian. Letaknya sendiri juga berada di dekat perbatasan degan Kabupaten Konawe sebelah utara. Sekolah bisa dikatakan jauh dari keramaian kota dimana di sekitarnya merupakan rumah dan kebun penduduk setempat. Sekolah ini mulai beroperasi pada tahun 1984 namun masih berstatus akreditasi masih $\mathrm{C}$.

Pembiayaan operasional sekolah berasal dana Bantuan Opersional Sekolah (BOS). Prasarana ruang sekolah ini cukup memadai apabila dibandingkan dengan rasio siswa yaitu; ruang kantor, perpustakaan, ruang guru, ruang kelas sebanyak 6 ruang, rumah 
dinas kepala Sekolah, ruang UKS serta WC 4 buah. Letak sekolah berada di atas lahan seluas $1.437 \mathrm{~m}^{2}$. Pada tahun pelajaran 2014/2015, jumlah total siswa yaitu 97 siswa yang tersebar di 6 kelas yang kesemuanya beragama Islam. Data lengkap siswa SDN 12 Mandonga dapat dilihat pada tabel berikut:

Tabel 3. Jumlah Siswa SDN 12 Mandonga Tahun Pelajaran 2014/2015

\begin{tabular}{|l|l|c|c|c|}
\hline No & Kelas & Laki-laki & Perempuan & Jumlah \\
\hline 1 & Kelas 1 & 7 & 9 & 16 \\
\hline 2 & Kelas 2 & 5 & 3 & 8 \\
\hline 3 & Kelas 3 & 11 & 8 & 19 \\
\hline 4 & Kelas 4 & 8 & 11 & 19 \\
\hline 5 & Kelas 5 & 16 & 3 & 19 \\
\hline 6 & Kelas 6 & 8 & 8 & 16 \\
\hline \multicolumn{2}{|l}{ Jumlah } & 55 & 42 & 97 \\
\hline
\end{tabular}

Secara umum, guru yang bertugas di SDN 12 Mandonga sebanyak 11 orang, delapan yang berstatus PNS dan tiga berstatus Non PNS. Guru yang bertugas pada mata pelajaran PAI-BP di SDN 12 Mandonga hanya satu $\mathrm{Hj}$. Sartina Mauqi, A.Ma., lulusan D2 Jurusan PAI tahun 2006. Walaupun secara akademik masih lulusan diploma namun sudah sangat lama bertugas sehingga memiliki pengalaman mengajar yang cukup panjang. Sejak tahun 1982, ia diangkat sebagai PNS dalam jabatan Guru PAI dan mengabdi pada 4 Sekolah Dasar yang berbeda di Sulawesi Tengggara. Namun, ia baru memperoleh sertifikat pendidik pada tahun 2010 . Disamping itu juga, selama bertugas ia baru mengikuti satu kali diklat yang diadakan oleh Disdikbud. Kini pengabdiaannya memasuki usia hampir pensiun. Kenyataan ini tentu perlu diantisipasi dengan pengusulan tenaga baru guru PAI di SDN Mandonga agar proses pembelajaran PAI dapat terlaksana sesuai dengan standar pendidikan.

\section{Visi Sekolah}

Mewujudkan sekolah ber-prestasi, berwawasan iptek, memiliki disiplin tinggi berlandaskan iman dan takwa.

\section{Misi Sekolah}

a. Menumbuhkan penghayatan terhadap ajaran agama yang dianut juga budaya bangsa.

b. Melaksanakan pembelajaran dan bimbingan secara efektif.

c. Menumbuhkan semangat keunggulan secara intensif kepada seluruh warga sekolah.

d. Menjadikan lingkungan sebagai sumber belajar.

e. Mewujudkan suasana kekeluargaan yang rukun dan harmonis antara warga sekolah dan lingkungan.

\section{Ketersedian Buku PAI-BP}

Tak dapat dipungkiri bahwa sumber belajar yang paling penting adalah buku. Oleh karena itu, keberadaan buku paket di sekolah adalah sesuatu yang wajib. Pada bagian ini akan dipaparkan ketersediaan buku PAI-BP di SDN 12 Baruga dan SDN 12 Mandonga. Sebagaimana yang telah disebutkan sebelumnya bahwa SDN 12 Baruga adalah salah satu sekolah menjadi pilot project dari Kementerian Pendidikan sehingga kurikulum yang digunakan yaitu kurikulum 2013. Namun demikian, kurikulum 2013 baru diterapkan di kelas 1, kelas 2, kelas 4 dan kelas 5 termasuk pada mata pelajaran PAI-BP. 
Pada tahun pelajaran 2013/2014 sebagai tahun pertama pemberlakuan kurikulum 2013, sekolah ini sebagai sekolah Pilot Project pemberlakuan kurikulum 2013 pernah mendapatkan bantuan dari Dinas Pendidikan dan Kebudayaan Kota Kendari berupa PAI-BP Kurikulum 2013 untuk kelas 1 sebanyak 113 ekslampar dan kelas 4 sebanyak 146 ekslampar. Keberadaan buku ini cukup membantu guru PAI dalam melakukan pembelajaran PAI-BP. Namun, pada tahun kedua bantuan buku tersebut sudah tidak ada lagi. Oleh karena itu, pihak sekolah berinisiasi mengadakan buku PAI dengan memesan pada penerbit untuk Kelas 2 dan kelas 5 di samping kelas 1 dan kelas 4 dengan menggunakan dana Bos. Buku yang diterbitkan Tiga Serangkai ini judul "Tuntutan Pendidikan Agama Islam dan Budi Pekerti, Pendekatan Saintifik K13". Sementara untuk kelas 3 dan kelas 6 tetap menggunakan kurikulum KTSP 2006 dengan buku terbitan Tiga Serangkai yang berjudul "Teladan Mulia Pendidikan Agama Islam.

Secara umum, kuantitas buku PAI-BP di SDN 12 Baruga cukup tinggi berbanding lurus dengan jumlah siswa yang jumlahnya sampai 996 siswa. Namun, yang menjadi kendala adalah ketersediaan buku yang masih belum sesuai standar 1:1 antara buku dan siswa. Oleh karena itu, guru mata pelajaran menganjurkan pada (orang tua) siswa yang ingin memiliki buku PAI-BP agar mencari sendiri di pasaran atau dengan menfotokopy. Disamping itu juga, guru PAI yang bersangkutan berusaha menprintout secara berkala materi PAI-BP yang didonload dari internet .

Sementara itu di SDN 12 Mandonga, walaupun sempat menggunakan kurikulum 2013, khusus untuk untuk mata pelajaran PAI-BP sejauh ini kurikulum yang digunakan tetap pada kurikulum KTSP 2006 dengan pertimbangan kompetensi guru PAI yang belum bisa memberlakukan kurikulum 2013. Di samping itu juga belum adanya ketersediaan buku PAI-BP kurikulum 2013. Bahkan, ketersediaan buku PAI-BP kurikulum KTSP 2006 pun masih sangat minim. Ini bisa dilihat kuantitas buku yang dimiliki sekolah yaitu untuk kelas 1, Kelas 2, dan Kelas 3, jumlah buku hanya 1 untuk guru, tidak ada buku untuk siswa. Sedangkan untuk kelas 4, Kelas 5, dan Kelas 6, jumlah buku sekitar 10 ekslampar/kelas. Angka ini tentu merupakan jumlah yang sangat miris untuk dijadikan harapan dalam meningkatkan kualitas pembelajaran agama Islam di sekolah. Kenyataan ini terjadi akibat kurang pedulinya pengambil kebijakan di SDN 12 Mandonga terhadap mata pelajaran PAI-BP. Bukti nyata dari itu yaitu pengadaan buku PAI-BP sudah sangat lama tidak ada pengadaan. Pihak sekolah justru mengharapkan bantuan pengadaan dari dinas terkait padahal mereka sudah dibekali dana Bantuan Operasional Sekolah yang di dalamnya terdapat item pengadaan buku mata pelajaran termasuk buku PAI.

Berbincang soal kewenangan dan tanggung jawab keberadaan buku PAI-BP untuk kurikulum 2013 di Sekolah Dasar, berdasarkan wawancara dengan pihak 
Kementerian Agama Provinsi Sulawesi Tenggara disebutkan penyalurannya adalah di bawah kewenangann mereka hanya saat ini bermasalah pada problem percetakan di tingkat pusat. Di satu pihak Kemendikbud merasa sama-sama berwenang, hanya sejauh ini Kemendikbud cuma menyalurkan buku PAI dengan pendekatan K13 ke Sekolah Dasar untuk kelas 1 dan 4. Sementara untuk pengadaan buku PAI-BP Kurikulum KTSP 2006, kewenangan ini mutlak di tangan masing-masing sekolah yang sudah mempunyai dana Bantuan Operasional Sekolah. Di samping itu juga, sudah banyak penerbit penerbit buku PAI yang membuka cabang di Kota Kendari sehingga pihak sekolah apabila ingin memperoleh dan mengadakan buku PAI-BP bisa menghubungi pihak penerbit tersebut.

\section{Mekanisme Pemanfaatan Buku PAI-BP di Sekolah Dasar}

Menurut Undang-undang

Nomor 20 Tahun 2003 Tentang

Sistem Pendidikan Nasional

disebutkan pada pasal 1 ayat 19

bahwa "Kurikulum adalah

seperangkat rencana dan pengaturan mengenai tujuan, isi, dan bahan pelajaran serta cara sebagai panduan penyelenggaraan kegiatan pembelajaran untuk mencapai tujuan pendidikan tertentu." Seperti dijelaskan sebelumnya bahwa di SDN 12 Baruga diberlakukan kurikulum 2013 berdasarkan instruksi dari Kementerian Pendidikan yang menetapkan sekolah ini sebagai Sekolah Pilot Project. Pada dasarnya, kebijakan ini pun sangat didukung oleh seluruh stekholder di sekolah baik Kepala Sekolah maupun guru agama. Walaupun pada dasarnya menurut mereka konten dari kurikulum KTSP 2006 dan kurikulum 2013 tidak jauh kecuali dari aspek penilaian. Oleh karena itu, didasari dari keinginan untuk selalu berinovasi, bagi mereka sesuatu yang baru yang selama itu bertujuan positif harus bisa diakomodasi dengan beradaptasi sejak dini.

Keberadaan edaran Menteri Pendidikan Dasar dan Menengah untuk kembali ke kurikulum KTSP 2006 karena alasan kurikulum 2013 belum secara utuh siap dioperasionalkan berimplikasi banyaknya sekolah kembali ke kurikulum KTSP 2006. Edaran ini tidak membuat SDN 12 Baruga ikut terbawa arus karena edaran ini hanya berlaku bagi sekolah yang baru memberlakukan 1 semester. Edaran ini sebenarnya memberikan ruang bagi SDN 12 Baruga untuk kembali ke KTSP jika dilandasi dengan alasan ketidakmampuan namun kata tidak mampu tidak ada dalam kamus mereka.

Hingga kini dengan berbagai keterbatasan yang dimiliki, SDN 12 Baruga tetap berusaha berinovasi dalam mengembangkan sekolah baik dalam hal saran dan prasarana, kualitas pembelajaran termasuk pembelajaran PAI yang sangat dirasa penting oleh pihak sekolah. Ini tertuang secara khusus yang berbunyi "Unggul dalam prestasi, berakhlak mulia, ber IPTEK dan berbudaya lingkungan". Visi ini selalu diusahakan untuk dimanifestasikan dengan selalu unggul dalam kompetisi antar Sekolah Dasar di berbagai bidang, menjadikan sekolah 
ini sebagai sekolah unggulan dan percontohan di Kota Kendari.

Sementara di SDN 12 Mandonga, pada awal tahun pelajaran 2014/2015, kurikulum 2013 sebenarnya sudah diterapkan. Hanya saja untuk mata pelajaran PAI, kebijakan tidak diberlakukan oleh sekolah karena keterbatasan sumber daya manusia serta media belajar berupa buku teks. Oleh karena itu sekolah tetap menggunakan kurikulum KTSP 2006. Pada dasarnya, kepala sekolah juga sangat mengharapkan kurikulum 2013 bisa diterapkan secara penuh di SDN 12 Mandonga dengan catatan diiringi dengan peningkatan sumber daya manusia dengan penambahan guru karena guru yang ada sudah memasuki usia jelang pensiun sehingga ekspetasi tidak dibebankan pada guru. Di samping itu, juga perlu peningkatan sarana dan prasarana khususnya berupa buku teks.

Pada dasarnya, penerapan kurikulum dalam pembelajaran di kelas di Kota Kendari, kepala sekolah menyerahkan sepenuhnya guru. Kebijakan ini diberlakukan oleh kepala sekolah karena menganggap bahwa para guru lebih mengetahui plus minus pembelajaran. Peran kepala sekolah dalam pemberlakuan kurikulum hanya sebatas pembimbing dan pengawas. Oleh karena itu, terkait dengan proses dan hasil pembelajaran sejauh ini tidak ada intervensi dari kepala sekolah. Pada akhirnya yang menentukan kualitas output dari pembelajaran PAI sangat ditentukan oleh dukungan manajemen dari kepala sekolah, kreatifitas guru dalam pembelajaran serta ketersediaan buku PAI serta keaktifan siswa dalam pembelajaran. Dalam hal ini, dukungan manajerial, kreatifitas guru serta ketersediaan buku lebih kuat di SDN 12 Baruga sebagai sekolah unggulan di Kendari. Realitas ini berbanding terbalik dengan yang terjadi di SDN 12 Mandonga dimana kepala sekolah seakan kurang mendukung pembelajaran. Indikatornya yaitu pada kelas tertentu siswa tidak memiliki buku pegangan dalam pembelajaran karena belum ada pengadaan buku memakai PAI-BP. Di satu sisi, siswa tidak bisa memiliki sendiri buku pegangan karena pada umumnya berasal dari keluarga yang kurang mampu.

Sebagaimana disebutkan bahwa efektifitas pembelajaran PAI di Sekolah sangat tergantung dengan keberadaan buku pegangan buat siswa. Salah satu faktor yang turut mempengaruhi pemilihan metode belajar yaitu ketersediaan fasilitas. Masalahnya yaitu tidak semua sekolah memiliki fasilitas, sarana dan media belajar yang lengkap. Dalam kondisi tertentu, guru-guru yang memiliki semangat, komitmen serta kreatifitas tetap mampu menjalankan pembelajaran yang menarik, menyenangkan serta mampu mencapai tujuan pembelajaran (Anas, 2014: 6). Bukti tersebut bisa dilihat pada kasus di SDN 12 Baruga dan SDN 12 Mandonga. Khusus untuk kasus di SDN 12 Baruga dimana hampir semua siswa memiliki pegangan yang diadakan langsung oleh sekolah maupun inisitaif dari siswa sendiri untuk memiliki. Di samping itu juga, salah inisiatif guru menanggulangi kekurangan buku yaitu dengan 
mendonload buku Kurikulum 2013 versi elektronik dari internet. Pada setiap pembelajaran, buku tersebut digunakan oleh siswa di samping menyimak penjelasan materi dari guru. Metode yang digunakan oleh guru pun masih konvesional yaitu metode direct (langsung), tanya jawab, dan memberikan penugasan baik berupa PR, ulangan harian dan ulangan semester.

Seperti halnya di SDN 12 Baruga, keberadaan buku paket sangat dibutuhkan oleh siswa dalam pembelajaran. Oleh karena, minimnya buku PAI di SDN 12 Mandonga menjadi kendala yang begitu sangat terasa bagi siswa dan guru. Kenyataan ini semakin diperparah dengan realitas bahwa mayoritas siswa sekolah berasal dari keluarga yang kurang mampu sehingga menyulitkan memiliki buku teks secara pribadi. Di samping itu, nampaknya pihak sekolah kurang memperhatikan pengadaan buku teks PAI. Oleh karena, metode yang digunakan oleh guru pada kelas tertentu yang metode mendiktekan materi kepada siswa, lalu siswa kemudian mencatat pada buku catatan. Akibatnya sebagian besar waktu untuk penjelaran dihabiskan oleh siswa untuk menulis materi.

Secara umum, pembelajaran dengan buku PAI berjalan cukup baik, kondusif, siswa menerima dan menyimak materi pelajaran yang diberikan oleh guru. Peran buku PAI sendiri relatif sangat penting dalam meningkatkan pemahaman siswa terhadap ajaran agama Islam. Hal ini diakui oleh masing-masing guru. Hanya saja dengan keterbatasan jumlah buku, dibutuhkan kreatifitas dari guru dalam mensiasati pembelajaran. Oleh karena itu, dukungan dan peran pengambil kebijakan di tingkat sekolah dalam hal ini kepala sekolah sangat diperlukan terlebih visi utama dari kedua sekolah mengacu pada peningkatan keimanan dan ketakwaan kepada Allah SWT.

Khusus untuk praktikum seperti praktek ibadah dan membaca Alquran, kedua sekolah menggunakan buka pegangan yang lain seperti praktek ibadah dan buku iqra'. Keberadaan buku ini dianggap masih kurang oleh guru. Misalnya, pada SDN 12 Mandonga, di samping materi diberikan berdasarkan buku PAI, materi baca tulis Alquran diberikan pada siswa dengan menggunakan buku paket Iqra. Sementara media belajar yang lain berkaitan langsung dengan materi PAI yang juga bisa mendukung praktikum hampir tidak ada kecuali poster praktek salat.

\section{Problem yang Dihadapi dalam Pemanfaatan Buku PAI-BP}

Secara umum, pemanfaatan buku PAI-BP di SDN 12 Baruga dan SDN 12 Mandonga berjalan dengan baik dimana kewenangan sepenuhnya ada di tangan Guru PAI. Namun demikian terdapat beberapa kendala diantaranya jumlah rombel yang berlebih di SDN 12 Baruga yaitu 24 rombel dengan hanya memiliki dua guru PAI sehingga menyulitkan bagi guru PAI dalam pengorganisasi waktu pembelajaran. Oleh karena itu, dibutuhkan peran pemerintah dalam hal pemerataan Guru PAI di sekolah berdasar rasio jumlah siswa yang dimiliki oleh sekolah sehingga pembelajaran terlaksana dengan efektif. 
Faktor kemampuan guru merupakan salah satu faktor yang mempengaruhi pembelajaran diantaranya metode yang digunakan. Walaupun demikian guru juga manusia yang memiliki keterbatasan tetapi tidak boleh menjadi alasan pembatas kreativitas. Namun, di satu sisi terkadang guru tidak memiliki ruang melakukan inovasi dan eksplorasi dengan segala keterbatasan yang dimiliki. Sehingga seringkali menyebabkan proses pembeljaran di kelas sekedar mencapai target administratif (Yunanto, 2004: 4).

Namun, setiap stekholder terkait tentu bertanggung jawab dalam peningkatan kualitas guru.

Salah satu problem pemanfaatan Buku PAI di sekolah yaitu yang berkaitan dengan dengan kompetensi guru itu sendiri. Misalnya kesiapan guru dalam menerapkan kurikulum baru dalam hal ini kurikulum 2013 masih kurang. Guru PAI yang ada di Kota Kendari belum semuanya pernah mengikuti Diklat yang terkait dengan profesinya terlebih yang terkait langsung dengan diklat kurikulum 2013. Bahkan diantara guru di kedua sekolah tersebut juga pernah mengikuti bimbingan teknis kurikulum 2013 yang selama ini diadakan oleh Kementerian. Ini tentu menjadi kendala serius yang biasanya terjadi setiap perubahan konsep kurikulum. Sosialisasi kurikulum adalah salah satu kunci sukses implementasi kurikulum oleh karena sangat dilakukan segera. Mulyasa menganjurkan agar dalam sosialisasi, pemerintah mengembankan grand design yang jelas dan menyeluruh, agar konse kurikulum yang diimplementasikan dapat dipahami oleh pelaksana secara utuh, tidak ditangkap secara parsial atau keliru (Mulyasa, 2014: 48).

Seperti disebutkan sebelumnya, bahwa rasio buku PAI di kedua sekolah belum memenuhi rasio 1:1. Kenyataan in juga menjadi problem utama dalam pembelajaran PAI hampir di setiap sekolah. Misalnya, di SDN 12 Mandonga pada kelas 1, kelas 2 dan kelas 3, guru PAI masih menggunakan metode mendiktekan materi pada siswa karena buku tidak dimiliki oleh siswa. Di sisi lain, karena buku teks kurikulum 2013 belum terdistribusi dengan baik, maka di SDN 12 Baruga masih memadukan antara buku teks kurikulum 2013 dan KTSP 2006. Kenyataan ini juga menjadi kendala tersendiri sekaligus menjadi tambahan pekerjaan bagi guru PAI. Realitas ini sebenarnya tidak terlalu dikeluhkan oleh guru PAI SDN 12 Baruga. Karena bagi mereka, dari sisi konten pada dasarnya kurikulum 2013 dan KTSP 2006 tidak memiliki perbedaan mencolok. Perbedaan yang paling esensial yaitu ada pada aspek penilaian dimana penilaian Kurikulum 2013 lebih komprehensif dengan menekankan pada kompetensi, sikap spritual, sikap sosial, keterampilan dan pengetahuan sebagaimana yang tercantum dalam pasal 3 ayat 3 Permendikbud Nomor 57 Tahun 2014 Tentang Kurikulum 2013 di Sekolah Dasar/Madrasah Ibtidaiyah.

Kurikulum 2013 yang
merupakan pengembangan dari
kurikulum sebelumnya memiliki
perbedaan, salah satunya yaitu pada
perspektif tata kelola. Jika di KTSP
2006 peran sekolah atau guru lebih


dominan dalam penyediaan buku teks dan buku untuk pengayaan, maka di kurikulum 2013, Mulyasa menyebutkan pemerintah harus menyiapkan; (1) buku pegangan pembelajaran terdiri dari buku siswa dan buku guru (2) menyiapkan guru supaya supaya memahami pendayagunaan sumber belajar yang telah disiapkan dan sumber lain yang dapat dimanfaatkan (3) memperkuat peran pendampingan dan pemantauan oleh pusat dan daerah dalam pelaksanaan pembelajaran (Mulyasa, 2014: 168). Namun, ketiga point tersebut nampaknya belum terlaksana secara maksimal di Kota Kendari. Salah satu penyebabnya adalah adanya missed atau kurang kordinasi antara pihak Kementerian Agama yang membawahi seksi pendidikan agama dan keagamaan di sekolah dengan Dinas Pendidikan dan Kebudayaan Kota Kendari dalam penerapan dan pengadaan buku Kurikulum 2013 PAI-BP.

Keberadaan buku PAI di sekolah belum mencapai rasio 1:1 tentu menjadi sebuah maslah besar dalam pembelajaran PAI. Oleh karena sebahagian guru menganjurkan pada siswa yang hendak memiliki sendiri buku agar menfotocopy atau mencari di toko buku. Namun, kenyataannya buku PAI di pasaran atau di toko buku di Kota Kendari jumlahnya juga sangat minim. Bahkan untuk Kurikulum 2013 sejauh ini belum ada di pasaran. Kenyataan yang sama juga terjadi di perpustakaan daerah di Kota Kendari yaitu tidak ada koleksi buku tingkat Sekolah Dasar maupun menengah. Belum lagi jika dilihat dari fungsi perpustakaan sekolah yang jauh ini tidak bisa menjalankan fungsi sebagai penyedia sumber pustaka dan informasi. Satu hal yang mungkin cukup menggembirakan yaitu keberadaan penyalur penerbit buku di Kota Kendari sehingga pihak sekolah bisa memesan langsung walaupun sejauh ini hanya terbatas pada buku kurikulum KTSP 2006.

Dari sisi konten buku, guru PAI juga mengeluhkan bahwa dari perspektif susunan bahasa masih dianggap kurang sederhana, Buku PAI yang ada masih sulit dicerna dan dipahami secara langsung oleh siswa oleh karena dibutuhkan penjelasan lebih lanjut dari guru terutama yang berkaitan dengan Alquran. Di samping itu, materi buku masih dianggap kurang lengkap sehingga diperlukan buku lain seperti: buku Iqra, panduan ibadah dan lain-lain.

Secara khusus, susunan materi kurikulum 2013 dianggap guru PAI di SDN 12 Baruga tidak sesuai dengan silabus yang telah ditetapkan. Di samping itu, susunan materi masih dianggap kurang tepat misalnya menempatkan materi Surah Al-Fatihah sebelum materi pengenalan huruf hijaiyyah.

\section{KESIMPULAN}

Berdasarkan pembahasan sebelumnya maka kesimpulan dari penelitian ini yaitu:

1. Secara umum, buku PAI yang tersedia di SDN 12 Baruga dan SDN 12 Mandonga belum memenuhi standar rasio 1:1 sehingga diperlukan kreatifitas guru dalam mengatasi problem ini agar pembelajaran tetap berjalan maksimal. Buku PAI yang tersedia di SDN 12 Baruga terlihat lebih lengkap dibandingkan yang terdapat di 
SDN 12 Mandonga. Buku PAI di SDN 12 Baruga terdiri dari buku PAI Kurikulum 2013 terbitan Kementerian Pendidikan dan Kebudayaan untuk Kelas 1 dan Kelas 4, Buku PAI pendekatan saintifik kurikulum 2013 terbitan Tiga Serangkai untuk kelas 2 dan 4 serta buku PAI kurikulum KTSP 2006 untuk setiap kelas (kecuali Kelas 5). Sedangkan buku PAI di SDN 12 Mandonga terdiri dari Buku Kurikulum KTSP 2006 terbitan Erlangga untuk Kelas 1, terbitan Tiga Serangkai untuk Kelas 2, Kelas 3 serta Kelas 5, dan terbitan Yudhistira untuk Kelas 4 dan Kelas 6.

2. Kurikulum yang digunakan di SDN 12 Baruga yaitu kurikulum 2013 untuk Kelas 1, Kelas 2, Kelas 4 dan Kelas 5 sambil dipadukan dengan buku PAI kurikulum KTSP 2006. Sementara di SDN 12 Mandonga menggunakan Kurikulum KTSP 2006 pada setiap kelas. Mekanisme pemanfaatan sepenuhnya diserahkan pada guru PAI. Metode yang digunakan secara yaitu metode ceramah langsung, tanya jawab (diskusi), serta evaluasi berupa ulangan harian dan ulangan semester. Buku PAI-BP dianggap cukup membantu bagi siswa dalam pembelajaran walaupun dari sisi materi masih kurang, misalnya untuk materi ibadah dan baca tulis Alquran masih diperlukan buku penunjang yang lain.
3. Kendala yang dihadapi dalam pemanfaatan Buku PAI di SDN 12 Baruga dan SDN 12 Mandonga diantaranya berkaitan dengan peran pengambil kebijakan yang masih kurang dalam pengadaan buku untuk sekolah. Problem lain yaitu yang berkenaan dengan kompetensi Guru dimana guru masih sangat jarang mengikuti diklat yang berkaitan dengan jabatannya. Kendala yang lain yaitu khusus untuk di SDN 12 Baruga memiliki rombongan belajar yang terlalu banyak yaitu 24 sementara guru PAI yang ada hanya dua orang. Di samping itu juga rasio buku PAI belum mencapai standar 1:1. Sementara problem yang berkaitan dengan konten buku yang dikeluhkan oleh guru PAI yaitu: susunan materi tidak sesuai dengan silabus untuk Kurikulum 2013 di SDN 12 Baruga, bahasa yang digunakan oleh buku teks masih kurang sederhana sehingga masih sulit dipahami siswa secara langsung serta materi buku masih dianggap kurang sehingga diperlukan buku lain seperti buku Iqra, panduan ibadah dan lain-lain.

\section{DAFTAR PUSTAKA}

Anas, Muhammad. 2014. Mengenal Metode Pembelajaran. t.p..

As'ad, Muhammad. 2009. et.al. Reformulasi Buku-buku Paket Madrasah.

Makassar: Idelenggara. 
Direktorat Pendidikan Agama Islam Direktorat Jenderal Pendidikan Islam Kementerian Agama RI. 2014. Panduan umum Implementasi Pendidikan Agam Islam dan Budi Pekerti. Jakarta: Direktorat Jenderal Pendidikan Islam Kementerian Agama RI.

Muhaimin. 2009. Pengembangan Kurikulum Pendidikan Agama Islam di Madrasah dan Perguruan Tinggi. Jakarta: Raja Grafinndo Persada.

Mulyasa. 2014. Pengembangan dan Implementasi Kurikulum 2013.Bandung: Remaja Rosda Karya.

Muslim, Abu. "Problematika Pemanfaatan Buku Paket Pendidikan Agama Islam Sekolah Dasar Di Kota Balikpapan." Jurnal Edukasi Volume 14 Nomor Tahun 2016.

Peraturan Menteri Pendidikan dan Kebudayaan Nomor 103 Tahun 2014 Tentang Pendampingan Pelaksanaan Kurikulum 2013 Pada Pendidikan Dasar dan Pendidikan Menengah.

Peraturan Menteri Pendidikan dan Kebudayaan Nomor 105 Tahun 2014 Tentang Pembelajaran Pada Pendidikan Dasar dan Pendidikan Menengah.

Peraturan Menteri Pendidikan dan Kebudayaan Nomor 159 Tahun 2014 Tentang Evaluasi Kurikulum 2013.

Peraturan Menteri Pendidikan dan Kebudayaan Nomor 57 Tahun 2014 Tentang Kurikulum 2013 Sekolah Dasar/Madrasah Ibtidaiyah.
Peraturan Pemerintah RI Nomor 32

Tahun $2013 \quad$ Tentang

Perubahan Atas Peraturan

Pemerintah Nomor 19 Tahun

2005 Tentang Standar Nasional

Pendidikan.

Pusat Bahasa Departemen Pendidikan Nasional. Kamus Besar Bahasa Indonesia. Jakarta: Balai Pustaka, 2009.

Sugiyono. 2008. Memahami Penelitian Kualitatif. Cet. IV; Bandung: Alfabeta.

Surat Menteri Pendidikan dan Kebudayaan Nomor 179342/MPK/KR/ 2014 Tentang Pelaksanaan Kurikulum 2013.

Susilana, Rudi dan Cepi Riyana. 2009. Media Pembelajaran. Bandung: Wacana Prima.

Undang-undang Nomor 20 tahun 2003 tentang Sistem pendidikan Nasional

Yunanto, Sri Joko. 2004. Sumber Belajar Anak Cerdas. Jakarta: Grasindo. 